в некоторых районах центральной Боснии и боснийской Позавине. Со своей стороны мусульмане изгнали из Сараево сербов и хорватов (от 80 тыс. до 100 тыс. человек ушли вовремя в ходе бомбежок НАТО сербскобоснийский войск в марте 1995 года). Такая же чистка была осущест-влена и в других районах Федерации. Что касается сербов, то они отделались от мусульман и хорватов в Республике Сербской. Во всеобшей взаимокровавой "этнической чистке" главным средством были физический и психологический террор, варварские методы, применяемые в хорватских и сербских лагерях для военнопленных и, особенно, в сербском лагере Омарска, знаменитом своим насилием над женщинами. Мусульмане делали то же кровавое дело, в частности в лагерях Тарцине и Селебичах, но в меньших масштабах. Кроме того мусульмане проводили чистки среди бунтующих единоверцев самопровозглашенной "республики" в главе с сомнительным бизнесменом Фикретом Абдичем.

В общей сложности сейчас около 2 млн. боснийцев - сербов, хорватов и мусульман - являются беженцами. Часть из них живет за границей, другая часть - в Боснии и Герцеговине или в других республиках бывшей Югославии. Одна только Сербия приютила около 700 тыс. беженцев. Почти каждый из двух миллионов беженцев знает, что имеется очень мало шансов вернуться к своему очагу. Все или почти все они обречены на вечное изгнание.

В балканских войнах имеются победители, но там же постоянно рождается бешеная злоба и неистребимая потребность мести. Так что, история повторяется, и столкновения возобновляются, так как конфликты в прошлом "разрешались" с помощью жестоких методов. Отсюда и проистекает цепь ужасов под названием "этническая чистка", разорвать которую можно только политическими методами.

Статья поступила в редакцию в декабре 1999 г.

\title{
ПРАВО КОНТРОЛИРОВАТЬ СИЛУ. ВОЙНА НА БАЛКАНАХ
}

\author{
Моник Ш е р м и л ь е-Д ж е нд р о*
}

Восемь лет назад Соединенные Штаты Америки со своими союзниками от имени Организации Объединенных Наций вели военные действия против Ирака. Они также развязали войну против Республики Сербии, но уже от имени Организации Североатлантического договора без какой-либо ссылки на ООН, хотя она была и остается единственной международной организацией, в компетенции которой находятся вопросы войны и мира.

Все драматические события, театром которых стала бывшая Югосла-

*Профессор права университета Дени Дидро в Париже-VII. 
вия, настоятельно требуют от каждой конфликтующей стороны юридически обоснованной позиции. К международному праву, хотя оно довольно рудиментарно, рвутся как с одной, так и с другой стороны. Открытое или замаскированное принятие той или иной стороной позиции вынуждает говорить противоположные вещи о международном праве: или то, что никакое вмешательство в дела суверенного государства недопустимо и все национальные вопросы, какими бы они ни были, должны решаться в его политическом пространстве; или то, что вмешательство извне изощренно обосновано гуманитарными соображениями и наличием законной базы, содержащейся в определенных положениях резолюций Совета Безопасности ООН.

Одних любезностей здесь недостаточно ни для выхода из тупика, созданного ракетно-бомбовыми ударами НАТО, ни для сохранения шатких основ международного права, которое с конца "холодной войны" потерпело ряд, может быть, даже смертоносных поражений, оставив человечество в нынешний период глобализации без такого хрупкого инструмента, каковым является право. Хотя, если хорошенько подумать, оно даже сейчас содержит в себе возможности, которые могут заменить отсутствующую волю государственных деятелей.

Основной задачей ООН является поддержание мира на Земле, анализ различного рода обстоятельств, объявление угрозы миру или его нарушения. Ее Совету Безопасности здесь принадлежит главная роль, но не исключительная..Генеральная Ассамблея в отличие от Совета Безопасности включает в свой состав всех членов ООН с правом одного голоса для ка̄ждого из них, и она принимает решения простым большинством голосов. В соответствии со статьями 10 и 11 Устава ООН она также имеет право заниматься вопросами войны и мира. Искомый мир зиждется на мире между государствами, которому угрожают разногласия международного характера. Целью ООН является обеспечение и гарантия прав человека и права наций распоряжаться собой. Но иногда эти права не могут быть гарантированы при наличии нерешенных противоречий между внутригосударственными правами и международными обязательствами.

Современные конфликты могут принимать, как это видно на примере проблемы Косова, крайние формы, но при этом не выходить за пределы государства, Поскольку государство сегодня составляет ядро международного сообшества, правительство в своей политике может прикрыться принципом невмешательства во внутренние дела.

Это должно решаться в каждом конкретном случае отдельно. В свое время Генеральная Ассамблея ООН вывела колониальные вопросы из-под юрисдикции государств. Обычно СБ ООН вправе определять международный характер того или иного спорного вопроса. Если ответ утвердительный, то решать его следует мирными средствами (Глава 6 Устава ООН) или принудительными методами (Глава 7 Устава ООН). Использовав Главу 7 в связи с косовским кризисом, Совет Безопасности тем самым довольно серьезно ущемил суверенитет Сербии (имеются в виду резолюции 1160 от 31 марта 1998 г. и 1199 от 22 сентября 1998 г.).

Исходя первоначально из необходимости поддержания мира при постановке вопроса о Косове, СБ ООН в результате последующих своих 
действий или, вернее, своего бездействия оказался в катастрофической ситуации. СБ и вся ООН находится лишь на начальном долгом пути своей дискредитации. Нарушения положений Устава ООН были вопиющи во время войны в Персидском заливе. После принятия резолюции о военных действиях против Ирака СБ ООН оставил ее исполнение на совести государств-членов, которые взяли на себя военные и политические аспекты этого вопроса в нарушение 43-48 статей (резолюция 678 от 29 ноября 1990 г.). В ходе боснийского кризиса, СБ ООН, начиная с 1994 года, сотрудничал с НАТО, но не дал ни малейшего убедительного объяснения такому направлению своей деятельности.

Устав ООН предусматривает выделение ее СБ соответствующих вооруженных сил, которые никогда не предоставлялись ему. Впрочем, в главе VIII говорится, что "противоречия локального масштаба" могут быть урегулированы "региональными" организациями. Как видно, речь идет о кризисах и их урегулировании в географически ограниченных регионах. Некоторые объясняют отсутствие резолюций СБ ООН тем, что НАТО было делегировано применение силы в Боснии, и как предполагается в Косово. Но в таком случае это является нарушением процедуры (резолюция 1203 от 24 октября 1998 г.). НАТО, не являясь "региональной" организацией, предвосхищает выполнение плана США, то есть установление их господства над Севером и наведение порядка в хаотичных и неуправляемых регионах мира, в так называемых "серых зонах". Некоторые правительства с брюзжанием присоединяются $\mathrm{k}$ этому плану, так как в противном случае они сами не смогут справиться c "серыми зонами" и самостоятельно выйти на путь права и демократии.

Поле для маневра здесь остается очень узким. ООН является единственной законной организацией для решения проблем международного масштаба. Процедуры в данном случае вырисовываются альтернативными:

или Совет Безопасности ООН работает без права вето с реальным разделением ответственности между своими постоянными и непостоянными членами и в таком случае он должен полностью выполнять Главу VII (Устава), не игнорируя ни одного положения, что вынудит его самостоятельно выработать план использования вооруженных сил совместно с генеральным штабом (статья 46);

или Совет Безопасности ООН остается парализованным вето одного из пяти постоянных членов (Китай, Россия, США, Соединенное Королевство, Франция). Здесь необходимо вспомнить, ках при других обстоятельствах (с совершенно другой расстановкой сил) была пересмотрена компетенция между органами ООН и стала возможной интервенция в Корею (резолюция Дина Ачесона - 377 - названная "Объединение для поддержания мира" от 3 ноября 1950 г.). Чтобы ООН смогла выполнить свою задачу, компетенции ее Совета Безопасности были переданы Генеральной Ассамблее, бывшей более сговорчивой в отношении Соединенных Штатов и в которой положение обстоит далеко не так на сегодняшний день. Процедура использования Генеральной Ассамблеи ООН вместо ее Совета Безопасности повторялись после этого многократно. Для народов мира ГА ООН является более представительной. Кроме возможной ссылки на чисто обсуждаемые и поддерживаемые 
прецеденты, передача Генеральной Ассамблее компетенций СБ по вопросу Югославии в юридически приемлемых рамках была бы для малых и средних государств поводом $\mathrm{K}$ их возврашению на арену международной политики со своего нынешнего положения фантомных актеров или вообще нищих.

Для разрешения спорных вопросов Устав ООН предусматривает как дипломатию, так и вооруженную силу. В дипломатическом плане региональная конференция государств должна созываться под эгидой Генеральной Ассамблеи. Эти полномочия ГА дают гарантию использования всех положений Устава и Всеобшей декларации прав человека: защита прав на возврашение на родину, право народов распоряжаться собой, поддержание мира без ссылки на "временную администрацию", которая уже попахивает неоколониализмом. Генеральная Ассамблея ООН также правомочна принять решение, в случае вето СБ, продолжать военные действия.

Генсральная Ассамблея ООН столкнется с вопросом об отсутствии вооруженных сил, предусмотренных статьей 43 Устава. Необходимо создать их незамедлительно, иначе это будет концом ООН. На данный момент передача ответственности ООН региональной организации за военное вмешательство позволяет решить проблему отсутствия собственных вооруженных сил, но без права трансформации этой региональной организации в трансатлантическое образование с обшемировыми замашками. Европейский Союз окажет себе честь, если поставит перед Генеральной Ассамблеей ООН такую задачу, и если в то же время предоставит ООН необходимые вооруженные силы, что, в свою очередь, предосставит Европе право не только на оборону, но и на так ожидаемую самостоятельную политическую жизнь.

Статья поступила в редакцию в декабре 1999 г. 